\title{
Angiogenic activity of placental tissues of cows
}

\author{
L. P. Reynolds, D. S. Millaway, J. D. Kirsch, J. E. Infeld and D. A. Redmer \\ Department of Animal and Range Sciences, North Dakota State University, Fargo, \\ North Dakota 58105, U.S.A.
}

\begin{abstract}
Summary. In Exp. 1, maternal (caruncle) and fetal (cotyledon) portions of the placenta as well as uterine endometrium were obtained from cows at mid-gestation and evaluated for angiogenic activity by placing tissue samples on chick chorioallantoic membranes (CAM). Only caruncular tissues exhibited angiogenic activity in the CAM assay. In Exp. 2, lyophilized homogenates of caruncular tissues obtained from cows at mid-gestation were evaluated for angiogenic activity on CAM and for their ability to stimulate mitosis of bovine aortic endothelial cells in vitro. Homogenates of caruncular tissues again were angiogenic on the CAM and also were mitogenic for endothelial cells. In Exp. 3, maternal (caruncle and endometrium) and fetal (cotyledon and fetal membrane) portions of the placenta were obtained from cows at mid-gestation and fine minces (explants) of each were cultured for $24 \mathrm{~h}$. Explant-conditioned media were then tested for angiogenic activity by their abilities to stimulate mitosis and migration of bovine aortic endothelial cells in vitro. Conditioned media from caruncular explants, but not from explants of other tissues, exhibited both mitogenic and migrationstimulating activities. When pools of caruncular explant-conditioned media were fractionated by ultrafiltration, mitogenic activity was not present in fractions of $M_{\mathrm{r}}$ $<10000,<30000$ and $<100000$, but was retained in fractions of $M_{\mathrm{r}}>10000$, $>30000$ and $>100000$. Mitogenic activity was not observed in any fractions subjected to heat treatment. On the basis of these data, we conclude that, during mid-gestation, angiogenic activity of bovine placenta is associated primarily with the maternal caruncular portion of the placenta which, therefore, may direct growth of the placental microvasculature. This angiogenic activity seems to have a molecular weight of $>100000$ and be heat labile.
\end{abstract}

\section{Introduction}

Low birth weights are associated with increased morbidity and mortality of newborns in several mammalian species, including man (Record et al., 1952; Anderson et al., 1978; Fahmy et al., 1978; Huffman et al., 1985). Birth weight depends primarily on rate of fetal growth, which is highly correlated with placental weight (Ibsen, 1928; Warwick, 1928; McKeown \& Record, 1953; Alexander, 1964). The role of the placenta in determining rates of fetal growth and development probably depends, to a large extent, on development of an adequate placental blood supply (Barcroft, 1946; Barcroft \& Barron, 1946; Rosenfeld et al., 1974; Reynolds et al., 1986). Growth of placental vascular beds continues throughout gestation even though placental weight in ruminants is maximal by about midgestation (Barcroft, 1946; Hutchinson, 1962; Teasdale, 1976). Associated with growth of placental vascular beds throughout gestation is a corresponding increase in rates of uterine and umbilical blood flows as well as fetal oxygen and nutrient uptakes (Rosenfeld et al., 1974; Reynolds et al., 1986). In spite of the importance of angiogenesis to placental function, little is known about how development of the placental blood supply is directed. There is some indication, however, that the stimulus for growth of placental vascular beds may derive from the placenta itself, since vasoactive factors (e.g. prostaglandins, glycosaminoglycans) produced by the placenta 
have been shown to stimulate growth of microvasculature in other systems (Rankin, 1976; Form \& Auerbach, 1983; Greiss \& Wagner, 1983; West et al., 1985).

Ruminant placentas are classified by shape as cotyledonary because intimate contact between maternal and fetal tissues occurs only in discrete structures, termed placentomes, which comprise the most vascular portion of the placenta (Ramsey, 1982). This arrangement provides a unique opportunity to study differences not only between maternal and fetal portions but also between functionally specialized portions of the placenta. The purposes of the present study were to determine whether bovine placental tissues contain angiogenic activity and, if so, from which tissue(s) this activity derives.

\section{Materials and Methods}

Materials. For cell and tissue cultures, Dulbecco's Modified Eagle medium (DMEM), Eagle Minimal Essential medium (EMEM), MEM non-essential amino acids, calf serum, fetal bovine serum (FBS), trypsin, Trypan Blue stain $(0.4 \%)$ and penicillin-streptomycin $(10000 \mathrm{U}$ penicillin $\mathrm{G}$ sodium $/ \mathrm{ml}$ and $10000 \mu \mathrm{g}$ streptomycin sulphate/ml) were purchased from Gibco (Grand Island, NY). Dextrose, bovine serum albumin (BSA, fraction V), bovine pancreatic insulin, antibiotic-antimycotic solution, and ethylenediaminetetraacetate (EDTA) were purchased from Sigma (St Louis, MO). Plasma-derived horse serum used for culture of endothelial cells was from HyClone (Logan, UT). Fluorescent low density lipoprotein (acetylated LDL labelled with 1,1'-dioctadecyl-1-3,3,3',3'-tetramethylindocarbocyanine perchlorate; Biomedical Technologies, Cambridge, MA), antisera for Factor VIII-related antigen (Accurate Chemical and Scientific, Westbury, NY; Calbiochem-Behring, San Diego, CA), and radioassay kit for angiotensin-converting enzyme (Ventrex, Portland, ME) were used for the identification of endothelial cells.

Isolation of endothelial cells. Bovine aortic endothelial cells (BAEC) were obtained from thoracic aortas by using procedures similar to those of Redmer et al. (1985), except that cells were initially cultured in DMEM containing $20 \%$ plasma-derived horse serum and $1 \%$ penicillin-streptomycin. At the third and subsequent subcultures, BAEC were cultured in DMEM containing 10\% calf serum and 10\% FBS. At the sixth subculture, BAEC were frozen and then stored in liquid nitrogen until used for bioassays. The BAEC were identified as being endothelial cells by the following criteria (Shepro \& D' Amore, 1984): strict maintenance of a monolayer at confluence and cobblestone appearance, rapid uptake of fluorescent LDL, specific immunofluorescent staining for Factor VIII-related antigen (with both antisera), and expression of substantial angiotensin-converting enzyme activity ( $240 \mathrm{U} / 10^{6}$ cells).

Experimental procedures. Three experiments were conducted to evaluate angiogenic activity of bovine placental tissues. In Exp. 1, samples ( $\simeq 2 \mathrm{~g})$ of maternal (caruncle) and fetal (cotyledon) portions of the placentome, intercaruncular uterine endometrium and fetal semitendinosus muscle (control tissue) were obtained from 14 cows at slaughter on Day $133 \pm 7$ of gestation. Samples of corpus luteum, which previously have been shown to be highly angiogenic (Gospodarowicz \& Thakral, 1978; Redmer et al., 1985), were obtained at slaughter from 13 non-pregnant cows to serve as positive control tissue. All tissues were handled in a sterile fashion and were placed into siliconized glass Petri dishes containing DMEM. Tissue samples were minced and then transferred to fresh DMEM. Angiogenic activity of these samples was evaluated by measuring neovascularization ('spoke-wheel' response) using the chicken chorioallantoic membrane (CAM) bioassay. The CAM bioassay was similar to the false air sac technique described by Phillips \& Kumar (1979) except that 'windows' ( $1 \mathrm{~cm}$ square) were cut through the shell and shell membrane of each egg on Day 7 of incubation. On Day 8 of incubation of eggs, a single sample $(\simeq 5 \mathrm{mg})$ of each tissue was placed on each of 5 CAM (within $2 \mathrm{~h}$ after tissue collection). On Day 13 of incubation (5 days after placement of tissues samples) each CAM was evaluated in situ by using stereomicroscopy. Grading was done by 3-5 trained individuals without prior knowledge of the treatment to which each egg was assigned. The angiogenic response was graded 0 (no response), 1 (questionable response), 2 (spoke-wheel response), 3 (exceptional spoke-wheel response) or 4 (exceptional spoke-wheel response with hyperaemia) as described previously (Vu et al., 1985).

In Exp. 2, 1-g samples of caruncular tissue were obtained from 7 additional cows at slaughter on Day $133 \pm 5$ of gestation. In addition, $1-\mathrm{g}$ samples of corpus luteum were obtained from 7 non-pregnant cows at slaughter. Samples were minced, homogenized on ice in $2 \mathrm{ml}$ distilled water by using a Polytron (Brinkmann, Westbury, NY) and centrifuged at $1500 \mathrm{~g}$ for $30 \mathrm{~min}$ at $4^{\circ} \mathrm{C}$. The resulting supernatants then were lyophilized. By the use of previously described methods (Langer \& Folkman, 1976; Form \& Auerbach, 1983), one of the lyophilized samples of each tissue was incorporated into $1 \mathrm{~g}$ ethylene-vinyl acetate copolymer (Elvax, E.I. Dupont de Nemours, Wilmington, DE). Five discs ( $\simeq 1.5 \mathrm{~mm}$ diam. and $0.3 \mathrm{~mm}$ thick) were cut from each Elvax preparation, as well as from 3 control Elvax preparations to which no lyophilized homogenate had been added. Each disc was dialysed in sterile $0.15 \mathrm{M}-\mathrm{NaCl}$ overnight before being utilized in the CAM bioassay as described in Exp. 1. Prepared in this way, Elvax discs have been shown to achieve sustained release of lipids, proteins and other macromolecules when placed onto the CAM (Langer \& Folkman, 1976; Form \& Auerbach, 1983). For some of the cows, a duplicate lyophilized homogenate of caruncle or corpus luteum was redissolved in $2 \mathrm{ml}$ distilled water and evaluated for angiogenic activity in vitro by its ability to stimulate mitogenesis of BAEC in culture. The BAEC were preincubated $\left(37^{\circ} \mathrm{C} ; 5 \% \mathrm{CO}_{2}, 95 \%\right.$ air $)$ for $24 \mathrm{~h}$ in 24 -well plates $\left(35 \times 10^{3}\right.$ cells/well) in DMEM containing $10 \%$ calf serum, $10 \%$ FBS and $1 \%$ penicillin-streptomycin. 
After preincubation, medium was changed to a maintenance medium (DMEM with $5 \%$ FBS and $1 \%$ penicillinstreptomycin; 5 wells) or maintenance medium containing $20 \%(\mathrm{v} / \mathrm{v})$ redissolved homogenate (3 wells per tissue). After $72 \mathrm{~h}$ incubation, wells were rinsed with a $0.02 \%$ EDTA solution, lightly trypsinized $(0.05 \%$ trypsin, $0.02 \%$ EDTA), and number of BAEC per well determined by using a Coulter counter (model ZF, Coulter, Hialeah, FL). To ensure accuracy of counts obtained with the Coulter counter, aliquants were removed from some wells after trypsinization and cell counts were determined by using a haemocytometer. Cell counts determined by haemocytometer or Coulter counter were always within $5 \%$ of each other. In addition, aliquants from some wells were stained with Trypan Blue (0.2\%), and viability of BAEC was always at or near $100 \%$. Protein concentrations of redissolved homogenates were determined by the method of Lowry et al. (1951) with BSA used as the standard.

In Exp. 3, samples $(\simeq 2 \mathrm{~g})$ of caruncle, cotyledon, intercaruncular endometrium and intercotyledonary fetal membrane were obtained from 6 cows at slaughter on Day 180 of gestation. All tissue samples were handled in a sterile fashion and were placed into siliconized glass Petri dishes containing EMEM. Explants (193 $\pm 12 \mathrm{mg})$ of each tissue were placed into fresh EMEM, finely minced, blotted on sterile gauze and transferred to siliconized 50-ml glass culture tubes containing $10 \mathrm{ml}$ explant medium. Explant medium was similar to that described by Basha et al. (1979) and consisted of EMEM supplemented with dextrose ( $5 \mathrm{~g} / \mathrm{l})$, MEM non-essential amino acids $(10 \mathrm{ml} / \mathrm{l})$, bovine pancreatic insulin $(300 \mathrm{U} / 1)$ and antibiotic-antimycotic solution $(20 \mathrm{ml} / \mathrm{l}), \mathrm{pH} 7 \cdot 3$. Explant incubations were conducted under $5 \%$ $\mathrm{CO}_{2}, 95 \%$ air in a Dubnoff shaking water bath $\left(30 \mathrm{cycles} / \mathrm{min}, 37^{\circ} \mathrm{C}\right)$ for $24 \mathrm{~h}$. After incubation, explant-conditioned medium was collected and stored at $-80^{\circ} \mathrm{C}$ until assayed for mitogenic and migration-stimulating activities. Ability of conditioned media to stimulate mitosis of BAEC was evaluated as described above except that after $24 \mathrm{~h}$ preincubation in 24-well plates $\left(35 \times 10^{3}\right.$ cells/well), medium was changed to DMEM with $5 \%$ FBS and $1 \%$ penicillinstreptomycin (control medium, 6 wells) or control medium containing $20 \%(\mathrm{v} / \mathrm{v})$ conditioned media ( 3 wells for each tissue from each cow). The number of BAEC per well was determined $72 \mathrm{~h}$ later by using a Coulter counter. Ability of conditioned media to stimulate migration of BAEC was evaluated as described by Redmer et al. (1985). Microchemotaxis chambers (48-well; Neuro Probe, Bethesda, MD) with polycarbonate membranes $(8 \mu \mathrm{m}$ pores; Nuclepore, Pleasanton, CA) were used. The bottom portion of each well contained unconditioned explant medium (control, 5 wells) or unconditioned explant medium containing $30 \%(\mathrm{v} / \mathrm{v})$ conditioned media ( 3 wells for each tissue from each cow). The top portion of each well contained $58 \times 10^{3}$ BAEC in unconditioned explant medium. Microchemotaxis chambers were incubated $\left(37^{\circ} \mathrm{C}, 5 \% \mathrm{CO}_{2}, 95 \%\right.$ air $)$ for $5 \mathrm{~h}$. After incubation, non-migrated BAEC were wiped from the top of the membrane, and migrated BAEC (bottom of membrane) were fixed and stained (Diff-Quik, American Scientific Products, McGaw Park, IL). After the membrane was mounted on a glass slide, the number of BAEC that had migrated through the pores in the membrane was determined for each well as described by Redmer et al. (1985).

After finding that conditioned media from caruncle exhibited angiogenic activity, a pool was made of caruncular explant-conditioned media from each of the 6 cows. Two additional pools of caruncular explant-conditioned media were obtained, one from 4 cows slaughtered on Day 122 and another from 3 cows slaughtered on Day 142 of gestation. Samples $(2 \mathrm{ml})$ of each of these pools were fractionated by using a pressurized ultrafiltration cell with lowadsorption (YM series) membranes (Amicon, Lexington, MA) to obtain filtrates with molecular weight ranges of $<10000,<30000$ and $<100000$. In addition, retentates from each aliquant were resuspended in $2 \mathrm{ml}$ unconditioned explant medium to obtain fractions of $M_{\mathrm{r}}>10000,>30000$ and $>100000$. One-half of each fraction was placed into a water bath at $80^{\circ} \mathrm{C}$ for $30 \mathrm{~min}$ to determine whether angiogenic activity was heat-labile. The untreated and heattreated molecular weight range fractions then were utilized in the BAEC mitogenesis bioassay ( 3 wells per fraction) as described above, except that only $20 \times 10^{3}$ BAEC were initially plated into each well.

Statistical methods. Data were analysed statistically by using analysis of variance for a completely randomized design, and when the F-test was significant, differences between specific means were evaluated by using Bonferroni's $t$ test (Kirk, 1968). Data are reported as means \pm s.e.m.

\section{Results}

The results of Exp. 1 are shown in Table 1. The angiogenic response of CAM to caruncular tissues was greater $(P<0.05)$ than the responses to tissues from corpora lutea, both of which stimulated neovascularization more $(P<0.05)$ than did other tissues. Responses to intercaruncular endometrium, cotyledon and fetal muscle were similar. In Exp. 2, lyophilized homogenates of caruncle and corpus luteum incorporated into Elvax discs stimulated $(P<0.01)$ angiogenesis on the CAM compared with control Elvax discs (Table 2). Homogenates of caruncle and corpus luteum also contained potent mitogenic activity. Fourfold increases $(P<0.05)$ in numbers of BAEC after $72 \mathrm{~h}$ of incubation were observed with homogenates of caruncle and corpus luteum compared with medium alone (Table 3). In Exp. 3, conditioned media from explant incubations of caruncular tissue were mitogenic $(P<0 \cdot 01)$ for BAEC compared with unconditioned medium (Fig. 1a). In 
Table 1. Angiogenic responses of chick chorioallantoic membranes to various bovine tissues*

\begin{tabular}{lccccc}
\hline & Caruncle & $\begin{array}{c}\text { Corpus } \\
\text { luteum }\end{array}$ & $\begin{array}{c}\text { Intercaruncular } \\
\text { endometrium }\end{array}$ & Cotyledon & $\begin{array}{c}\text { Fetal } \\
\text { muscle }\end{array}$ \\
\hline $\begin{array}{l}\text { Response } \\
\text { No. of cows }\end{array}$ & $2 \cdot 4 \pm 0 \cdot 2^{\mathrm{a}}$ & $1 \cdot 8 \pm 0 \cdot 2^{\mathrm{b}}$ & $1 \cdot 2 \pm 0 \cdot 2^{\mathrm{c}}$ & $0 \cdot 7 \pm 0 \cdot 1^{\mathrm{c}}$ & $0 \cdot 7 \pm 0 \cdot 2^{\mathrm{c}}$ \\
\hline
\end{tabular}

*A single sample ( $\cong 5 \mathrm{mg}$ ) of each tissue was placed on each of 5 chorioallantoic membranes. Values are mean \pm s.e.m.

Values with different superscripts differ $(P<0.05)$.

Table 2. Angiogenic responses of chick chorioallantoic membranes (CAM) to lyophilized homogenates of bovine caruncular and luteal tissues

\begin{tabular}{lccc}
\hline & Caruncle & $\begin{array}{c}\text { Corpus } \\
\text { luteum }\end{array}$ & Control \\
\hline Response & $2 \cdot 6 \pm 0 \cdot 2^{\mathrm{a}}$ & $2 \cdot 2 \pm 0 \cdot 3^{\mathrm{a}}$ & $0 \cdot 1 \pm 0 \cdot 1^{\mathrm{b}}$ \\
$\begin{array}{l}\text { No. of cows or } \\
\text { control samples }\end{array}$ & 7 & 7 & 3 \\
$\begin{array}{l}\text { No. of CAM } \\
\text { evaluated* }\end{array}$ & 35 & 35 & 15 \\
\hline
\end{tabular}

Values are mean \pm s.e.m.

Values with different superscripts differ $(P<0.01)$.

*For each tissue (1 sample/cow) or control sample, a single Elvax disc was placed on each of 5 CAM.

Table 3. Stimulation of mitogenesis of bovine aortic endothelial cells by homogenates of bovine caruncular and luteal tissues

\begin{tabular}{lccc}
\hline & $\begin{array}{c}\text { Medium } \\
+ \\
\text { caruncular } \\
\text { tissue }\end{array}$ & $\begin{array}{c}\text { Medium } \\
+ \\
\text { CL }\end{array}$ \\
\hline $\begin{array}{l}\text { Cells }\left(\times 10^{3}\right) \\
\text { per well* } \\
\text { No. of cows or } \\
\text { control samples }\end{array} \quad 31 \pm 0 \cdot 8^{\mathrm{b}}$ & $117 \pm 34 \cdot 8^{\mathrm{c}}$ & $138 \pm 23 \cdot 7^{\mathrm{c}}$ \\
\hline $\begin{array}{l}\text { * Number of cells per well } \\
\text { incubation with test sample. }\end{array}$ & 5 & 6 \\
$\begin{array}{l}\text { Values are mean } \pm \text { s.e.m. } \\
\text { Values with different superscripts differ }(P<0.05) .\end{array}$
\end{tabular}

contrast, mitosis of BAEC was not affected by exposure to conditioned media from intercotyledonary fetal membrane, cotyledon or intercaruncular uterine endometrium for $72 \mathrm{~h}$ (Fig. 1a). Migration of BAEC also was stimulated $(P<0.05)$ by caruncular explant-conditioned media compared with unconditioned medium (Fig. 1b). Conditioned media from intercotyledonary and intercaruncular tissues had no significant effect on migration of BAEC. Cotyledonary explantconditioned media, however, inhibited $(P<0.01)$ migration of BAEC compared with unconditioned medium (Fig. 1b). 

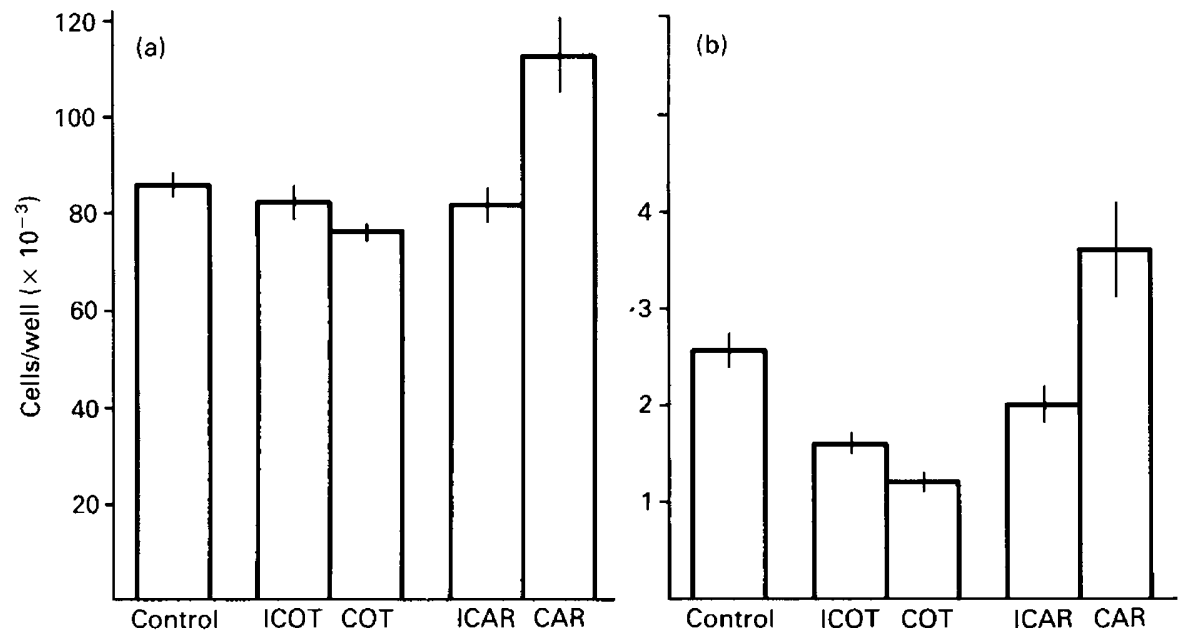

Fig. 1. Effects of explant-conditioned media from intercotyledonary fetal membrane (ICOT), cotyledon (COT), intercaruncular endometrium (ICAR) and caruncle (CAR) on (a) mitosis and (b) migration of endothelial cells.

Table 4. Effects of various fractions of caruncular explant-conditioned media pools on mitosis of bovine aortic endothelial cells*

\begin{tabular}{|c|c|c|c|c|c|c|c|}
\hline & \multirow[b]{2}{*}{ Unfractionated } & \multicolumn{6}{|c|}{$M_{\mathrm{f}}$ values } \\
\hline & & $<10000$ & $>10000$ & $<30000$ & $>30000$ & $<100000$ & $>100000$ \\
\hline $\begin{array}{l}\text { Untreated } \\
\text { Heat-treated }\end{array}$ & $136 \cdot 5 \pm 3 \cdot 3$ & $90 \cdot 3 \pm 4 \cdot 4$ & $128 \cdot 2 \pm 4 \cdot 2$ & $88 \cdot 1 \pm 6 \cdot 5$ & $124 \cdot 0 \pm 6 \cdot 5$ & $100 \cdot 3 \pm 8 \cdot 1$ & $126 \cdot 3 \pm 4 \cdot 7$ \\
\hline$\left(80^{\circ} \mathrm{C}, 30 \mathrm{~min}\right)$ & $99 \cdot 5 \pm 3 \cdot 4$ & $98 \cdot 5 \pm 6 \cdot 4$ & $82 \cdot 0 \pm 3 \cdot 5$ & $96 \cdot 1 \pm 3 \cdot 4$ & $84.8 \pm 0.8$ & $91 \cdot 4 \pm 9 \cdot 1$ & $92.9 \pm 4.4$ \\
\hline
\end{tabular}

*Numbers of cells per well expressed as $\%$ ( \pm s.e.m.) of control wells. Control wells contained $47.0 \pm 3.0 \times 10^{3}$ cells (untreated; $n=19$ ) and $53.7 \pm 9 \cdot 1 \times 10^{3}$ cells (heat-treated; $n=8$ ) after $72 \mathrm{~h}$ incubation. Data obtained from 3 pools of media, each obtained from 3-6 cows at Days 122-180 of gestation.

The pools of caruncular explant-conditioned media also exhibited mitogenic activity and stimulated a $36 \%$ increase $(P<0.05)$ in numbers of BAEC at $72 \mathrm{~h}$ compared with unconditioned (control) medium (Table 4). When pools of caruncular explant-conditioned media were subjected to ultrafiltration, activity was not apparent in filtrates of $M_{\mathrm{r}}<10000,<30000$ and $<100000$ but was retained $(P<0.05)$ in fractions of $M_{\mathrm{r}}>10000,>30000$ and $>100000$ (Table 4). When the unfractionated pools or molecular weight fractions were heat-treated, mitogenic activity was no longer observed (Table 4).

\section{Discussion}

From the results of these experiments, it is concluded that (1) bovine caruncular tissues and tissue homogenates obtained during mid-gestation possess angiogenic activity, and (2) caruncular tissues secrete angiogenic activity when cultured in vitro. This activity was found only in conditioned media from caruncular explants and not in conditioned media from explants of intercaruncular 
endometrium, cotyledon or intercotyledonary fetal membrane. In fact, cotyledonary tissue had an inhibitory effect in the endothelial cell migration bioassay. Thus, the maternal placenta may direct placental vascularization. The proposal that maternal tissues direct placental vascularization at midgestation does not, however, eliminate the possibility that fetal placental tissues may modulate production of angiogenic factors. In addition, the site of production of placental angiogenic factors may change with stage of gestation. Some evidence exists in support of these proposals, since angiogenic activity has been found only in the maternal portion (decidua) and not the fetal portion of the human placenta at mid-gestation (Fuchs et al., 1985), whereas others have reported angiogenic activity in human fetal membranes (amnio-chorion) and placental cotyledons at term (Burgos, 1983). In addition, we have found angiogenic activity (BAEC mitogenesis bioassay) in cotyledon but not caruncle of ewes at Day 120 of gestation (Reynolds et al., 1987).

Proliferation of capillary vessels is thought to consist of at least three processes: fragmentation of existing capillary basement membrane, migration of endothelial cells from existing vessels and proliferation of endothelial cells (Shepro \& D'Amore, 1984). In the present study, maternal placental tissues have been shown to secrete a factor which stimulates two of these components of angiogenesis in vitro. The observation that bovine caruncular tissue is able to induce neovascularization of the chick chorioallantois, which represents a complete in-vivo angiogenic response, indicates that mitogenic and migration-stimulating activities observed in the present study indeed represent angiogenic factor(s).

Angiogenic factor from bovine maternal placenta appears to be of large molecular weight (possibly $>100000$ ) and also heat-labile. Angiogenic factors which are similar in molecular weight and are heat-labile have been found in other reproductive tissues, including ovarian follicles, corpus luteum and human placenta (Burgos, 1983; Buki \& Seppa, 1984; Fuchs et al., 1985; Koos, 1986; Redmer et al., 1987). Data on molecular weight of angiogenic factors should be interpreted with caution, however, since it has been shown that angiogenic activities from several tissues are molecules of $M_{\mathrm{r}} 200-800$ which are normally bound to a carrier of about $M_{\mathrm{r}} 100000$ (Weiss et al., 1979; Brown et al., 1980; Burgos, 1983; Kumar et al., 1983; Buki \& Seppa, 1984).

Placental and fetal weights are highly correlated (Eckstein et al., 1955; Alexander, 1964; Knight et al., 1977). Although placental growth (represented by placental size or weight) is maximal by about mid-gestation, growth of placental vascular beds continues throughout pregnancy (Barcroft, 1946; Hutchinson, 1962; Teasdale, 1976). A corresponding increase in rates of maternal placental (uterine) and fetal placental (umbilical) blood flows, as well as fetal oxygen and nutrient uptakes, is observed (Rosenfeld et al., 1974; Reynolds et al., 1986). Conditions associated with reduced rates of fetal growth (e.g. maternal genotype, increased number of fetuses, maternal nutrient deprivation, environmental heat stress), also are associated with reduced placental weights as well as decreased rates of uterine and umbilical blood flows and fetal oxygen and nutrient uptakes (Wallace, 1948; Alexander \& Williams, 1971; Wootton et al., 1977; Morriss et al., 1980; Reynolds et al., 1985; Ferrell \& Reynolds, 1987). About $80-90 \%$ of uterine and umbilical blood flows are distributed to the maternal and fetal portions of the placenta, respectively, and have been shown to be important determinants of the quantities of oxygen and nutrients taken up by the fetus (Makowski et al., 1968; Rosenfeld et al., 1974; Reynolds, 1986; Reynolds et al., 1986). Angiogenic factors produced by the placenta, which may be essential for development of placental vascular beds, probably therefore play a crucial role in the processes that ensure adequate supplies of oxygen and nutrients for growth of the fetus. From data presented in this paper, it can be concluded that the maternal placenta directs placental vascular growth and thereby may exert a significant influence on fetal growth and development.

We thank R. B. Danielson and T. J. Flakoll for care of animals; D. W. Zaeske for assistance at slaughter; and J. Berg for typing the manuscript. Journal Article No. 1541 of the North Dakota Agricultural Experiment Station; Projects ND1780, ND1782 and ND3710. 


\section{References}

Alexander, G. (1964) Studies on the placenta of the sheep. Placental size. J. Reprod. Fert. 7, 289-305.

Alexander, G. \& Williams, D. (1971) Heat stress and development of the conceptus in domestic sheep. $J$. agric. Sci., Cambr. 76, 53-72.

Anderson, G.B., Cupps, P.T., Drost, M., Horton, M.B. \& Wright, R.W., Jr (1978) Induction of twinning in beef heifers by bilateral embryo transfer. J. Anim. Sci. 46, 449-452.

Barcroft, J. (1946) Researches on Pre-natal Life. Thomas, Springfield.

Barcroft, J. \& Barron, D.H. (1946) Observations upon the form and relations of the maternal and fetal vessels in the placenta of the sheep. Anat. Rec. 94, 569-595.

Basha, S.M.M., Bazer, F.W. \& Roberts, R.M. (1979) The secretion of a uterine specific, purple phosphatase by cultured explants of porcine endometrium. Dependency on the state of pregnancy of the donor animal. Biol. Reprod. 20, 431-441.

Brown, R.A., Weiss, J.B., Tomlinson, I.W., Phillips, P. \& Kumar, S. (1980) Angiogenic factor from synovial fluid resembling that from tumors. Lancet $\mathbf{i}, 682-685$.

Buki, K. \& Seppa, H. (1984) A low-Mr chemoattractant for vascular endothelial cells. FEBS Letters 184, $254-258$.

Burgos, H. (1983) Angiogenic and growth factors in human amnio-chorion and placenta. Eur. J. Clin. Invest. 13, 289-296.

Eckstein, P., McKeown, T. \& Record, R.G. (1955) Variation in placental weight according to litter size in the guinea-pig. J. Endocr. 12, 108-114.

Fahmy, M.H., Holtman, W.B., MacIntyre, T.M. \& Moxley, J.E. (1978) Evaluation of piglet mortality in 23 two-breed crosses among eight breeds of pigs. Anim. Prod. 26, 277-285.

Ferrell, C.L. \& Reynolds, L.P. (1987) Blood flow and nutrient uptake of the gravid uterus, fetus and uteroplacenta of Hereford or Charolais cows bearing single or twin fetuses. J. Anim. Sci. 65 (Suppl. 1), in press.

Form, D.M. \& Auerbach, R. (1983) PGE 2 and angiogenesis. Proc. Soc. exp. Biol. Med. 172, 214-218.

Fuchs, A., Lindenbaum, E. \& Marcoudas, N.G. (1985) Location of the angiogenic activity in the pregnant human uterus. Acta anat. 124, 24I-244.

Gospodarowicz, D. \& Thakral, K.K. (1978) Production of a corpus luteum angiogenic factor responsible for proliferation of capillaries and neovascularization of the corpus luteum. Proc. natn. Acad. Sci., U.S.A. 75, 847-851.

Greiss, F.C. \& Wagner, W.D. (1983) Glycosaminoglycans: Their distribution and potential vasoactive action in the nonpregnant and pregnant ovine uterus. Am. J. Obstet. Gynecol. 145, 1041-1047.

Huffman, E.M., Kirk, J.H. \& Pappaioanou, M. (1985) Factors associated with neonatal lamb mortality. Theriogenology 24, 163-171.

Hutchinson, L.R. (1962) The hemodynamics of the isolated pregnant uterus of the cow (Bos taurus). M.S. thesis, Iowa State University. Ames.

Ibsen, H.L. (1928) Prenatal growth in guinea-pigs with special reference to environmental factors affecting weight at birth. J. exp. Zool. 51, 51-91.

Kirk, R.E. (1968) Experimental Design: Procedures for the Behavioral Sciences. Wadsworth, Belmont, CA.

Knight, J.W., Bazer, F.W., Thatcher, W.W., Franke, D.E. \& Wallace, H.D. (1977) Conceptus development in intact and unilaterally hysterectomized-ovariectomized gilts: interrelations among hormonal status, placental development, fetal fluids and fetal growth. J. Anim. Sci. 44, 620-637.

Koos, R.D. (1986) Stimulation of endothelial cell proliferation by rat granulosa cell-conditioned medium. Endocrinology 119, 481-489.

Kumar, S., Shahabuddin, S., Haboubi, N., West, D., Arnold, F., Reid, H. \& Carr, T. (1983) Angiogenesis factor from human myocardial infarcts. Lancet $\mathbf{8 3 4 6}$, $364-368$.

Langer, R. \& Folkman, J. (1976) Polymers for the sustained release of proteins and other macromolecules. Nature, Lond. 263, 797-799.

Lowry, D.H., Rosebrough, N.J., Farr, A.L. \& Randall, R.J. (1951) Protein measurement with the Folin phenol reagent. J. biol. Chem. 193, 265-275.

Makowski, E.L., Meschia, G., Droegemueller, W. \& Battaglia, F.C. (1968) Distribution of uterine blood flow in the pregnant sheep. Am. J. Obstet. Gynecol. $101,409-412$.

Mckeown, T. \& Record, R.G. (1953) The influence of placental size on foetal growth in man, with special reference to multiple pregnancy. J. Endocr. 9, $418-426$.

Morriss, F.H., Rosenfeld, C.R., Crandell, S.S. \& Adcock, E.W., III (1980) Effects of fasting on uterine blood flow and substrate uptake in sheep. $J$. Nutr. 110, 2433-2443.

Phillips, P. \& Kumar, S. (1979) Tumour angiogenesis factor (TAF) and its neutralisation by a xenogeneic antiserum. Int. J. Cancer 23, 82-88.

Ramsey, E.M. (1982) The Placenta: Human and Animal. Praeger, New York.

Rankin, J.H.G. (1976) A role for prostaglandins in the regulation of the placental blood flows. Prostaglandins 11, 343-353.

Record, R.G., Gibson, J.T. \& McKeown, T. (1952) Foetal and infant mortality in multiple-pregnancy. $J$. Obstet. Gynecol. Br. Emp. 59, 471-482.

Redmer, D.A., Rone, J.D. \& Goodman, A.L. (1985) Evidence for a non-steroidal angiotropic factor from the primate corpus luteum: stimulation of endothelial cell migration in vitro. Proc. Soc. exp. Biol. Med. 179, 136-140.

Redmer, D.A., Kirsch, J.D. \& Grazul, A.T. (1987) In vitro production of angiotropic factor by bovine corpus lutuem: Partial characterization of activities that are chemotactic and mitogenic for endothelial cells. In Regulation of Ovarian and Testicular Function (in press) Eds E. Anderson, D. Dhindsa, S. Kalra \& V. Mahesh. Plenum Press, New York.

Reynolds, L.P. (1986) Utero-ovarian interactions during early pregnancy: Role of conceptus-induced vasodilation. J. Anim. Sci. 62 (Suppl. 2), 47-61.

Reynolds, L.P., Ferrell, C.L., Nienaber, J.A. \& Ford, S.P. 
(1985) Effects of chronic environmental heat stress on blood flow and nutrient uptake of the gravid bovine uterus and foetus. J. agric. Sci., Camb. 104, 289-297.

Reynolds, L.P., Ferrell, C.L., Robertson, D.A. \& Ford, S.P. (1986) Metabolism of the gravid uterus, foetus and utero-placenta at several stages of gestation in cows. J. agric. Sci., Camb. 106, 437-444.

Reynolds, L.P., Infeld, J.E., Anthony, R.V., Keisler, D.H. \& Redmer, D.A. (1987) In vitro secretion of ovine placental factor that stimulates endothelial cell mitogenesis. J. Anim. Sci. 65 (Suppl. 1), in press.

Rosenfeld, C.R., Morriss, F.H., Jr., Makowski, E.L., Meschia, G. \& Battaglia, F.C. (1974) Circulatory changes in the reproductive tissues of ewes during pregnancy. Gynecol. Invest. 5, 252-268.

Shepro, D. \& D'Amore, P.A. (1984) Physiology and biochemistry of the vascular wall endothelium. In Handbook of Physiology, Section 2, Vol. IV, Part I, pp. 103-164. Eds E. M. Renkin \& C. C. Michel. American Physiological Society, Washington, D.C.

Teasdale, F. (1976) Numerical density of nuclei in the sheep placenta. Anat. Rec. 185, 187-196.
Vu, M.T., Smith, C.F., Burger, P.C. \& Klintworth, G.K. (1985) Methods in laboratory investigation: An evaluation of methods to quantitate the chick chorioallantoic membrane assay in angiogenesis. Lab. Invest. 53, 499-508.

Wallace, L.R. (1948) The growth of lambs before and after birth in relation to the level of nutrition. Part III. J. agric. Sci., Camb. 38, 367-401.

Warwick, B.L. (1928) Prenatal growth of swine. $J$. Morphol. Physiol. 46, 59-84.

Weiss, J.B., Brown, R.A., Kumar, S. \& Phillips, P. (1979) An angiogenic factor isolated from tumours: a potent low-molecular-weight compound. $\mathrm{Br}$. J. Cancer 40, 493-496.

West, D.C., Hampson, I.N., Arnold, F. \& Kumar, S. (1985) Angiogenesis induced by degradation products of hyaluronic acid. Science, N.Y. 228, 1324-1326.

Wootton, R., McFayden, I.R. \& Cooper, J.E. (1977) Measurement of placental blood flow in the pig and its relation to placental and fetal weight. Biol. Neonate 31, 333-339.

Received 9 February 1987 